\title{
Interaction of Cadmium, Calcium, and Amiloride in the Kinetics of Active Sodium Transport through Frog Skin
}

\author{
Makoto TAKADA and Hideo HAYASHI \\ Department of Physiology, Saitama Medical School, \\ Iruma-gun, Saitama, 350-04 Japan
}

\begin{abstract}
The epidermal effects of activator (cadmium) or inhibitors (calcium and amiloride) as well as their interactions in active $\mathrm{Na}$ transport through bullfrog abdorminal skin were analyzed kinetically. Cadmium at $1 \mathrm{~mm}$ increased the short circuit current (SCC) to $126 \%$. The Hill coefficient $(n)$ for the relation between $\left[\mathrm{Cd}^{2+}\right]$ and SCC was 0.737 , which indicated negative cooperation. Calcium at over $8 \mathrm{~mm}$ decreased the SCC to $80 \%$ at its maximum effect. Calcium inhibited the $\mathrm{Cd}^{2+}$-induced $\mathrm{SCC}$ at lower $\left[\mathrm{Cd}^{2+}\right]$, and facilitated it at higher $\left[\mathrm{Cd}^{2+}\right]$. Calcium acted uncompetitively on the binding reaction of $\mathrm{Na}^{+}$with a $\mathrm{Na}$ entry channel. $\mathrm{Cd}^{2+}$ alone or $\mathrm{Cd}^{2+}$ under the influence of calcium also acted uncompetitively on the reaction. Amiloride at $5 \times 10^{-5} \mathrm{M}$ inhibited the SCC almost completely. The Hill coefficient in the relation between amiloride and $\mathrm{SCC}$ was 0.757 , indicating the presence of negative cooperation. In contrast to the effect of calcium, the $\mathrm{Cd}^{2+}$-induced $\mathrm{SCC}$ was much reduced at higher [amiloride]. Amiloride inhibited the channel-Na binding reaction in a mixed manner (competitive + noncompetitive), while $\mathrm{Cd}^{2+}$ activated the reaction under the influence of amiloride noncompetitively. From the SCC model based on the hypothesis that the kinetic constants are invariable even under interaction of the activator and inhibitors, the percentage of the various forms of channel-ion complex were calculated. The SCC was then calculated, assuming that it was directly proportional to the sum of the rate of decomposition of channel $\cdot \mathrm{Na}$ complex and the higher rate of decomposition of channel $\cdot \mathrm{Na}$. $\mathrm{Cd}^{n}$ complex. The above assumption is supported by the fact that there is good agreement between the calculated SCC and experimentally obtained SCC in the mixture of the activator and the inhibitor.
\end{abstract}

Active $\mathrm{Na}$ transport by frog skin has been reported to be increased by the application of $\mathrm{Cd}^{2+}$ (Stymans and Borghgraef, 1969; Hillyard and GonicK, 1976; HAYASH et al., 1977). $\mathrm{Cd}^{2+}$ is considered to exert its effect on the outer facing membrane of the skin (HAYASHI et al., 1978; TAKADA and HAYASHI, 1978a, 1980a). The $\mathrm{Cd}^{2+}$ effect is not due to enhancement of $\mathrm{Na}$, K-ATPase activity

Received for publication September 12, 1980

高田真理, 林 秀生 
in the frog epidermis (TAKADA and HAYASHI, 1978b).

Many investigators have noted the inhibitory effect of $\mathrm{Ca}^{2+}$ and amiloride on Na transport through frog skin ( $c f$. Benos et al., 1979; ACEVES and CUTHBERT, 1979). They found that these inhibitors acted on the outer facing membrane and decreased the $\mathrm{Na}$ translocation. They also carried out kinetic studies on $\mathrm{Ca}^{2+}$ and amiloride effects. We therefore attempted to analyze the mechanism of the $\mathrm{Cd}^{2+}$ effect on $\mathrm{Na}$ translocation in more detail by comparing the action of calcium and/or amiloride.

The following hypotheses were discussed. (1) Na translocation can be described quantitatively in terms of channel-ion complexes and their dissociation constants. (2) Furthermore, the dissociation constants appeared never to be changed by the simultaneous application of the activator or inhibitors.

Preliminary descriptions of this work have been given elsewhere (TAKADA and HAYASHI, 1980b).

\section{MATERIALS AND METHODS}

The abdominal skin of bullfrogs (Rana catesbeiana) of both sexes was used. The frogs were captured in Saitama Prefecture, Japan, and kept at room temperature in a bath for a week or two without feeding. The water level was maintained so that about half of the body was immersed.

The frogs were anesthetized by intrathecal injection of $1 \mathrm{ml}$ per $\mathrm{kg}$ body weight of $0.25 \mathrm{~g} / \mathrm{ml}$ urethane solution. The abdominal skin was dissected out and mounted on the open tip of a glass cannula (8-12 $\mathrm{mm}$ inner diameter), with the dermal side facing the inside of the cannula. Both sides of the skin were soaked in aerated Ringer's solution. The hydrostatic pressure difference between the epidermal and dermal sides was nullified by adjusting the saline levels. $\mathrm{SO}_{4}$ Ringer's solution (see Table 1 for various [Ca gluconate] and Table 2 for various $\left[\mathrm{Na}^{+}\right]$) was used to eliminate the possible influence of passive and active transport of $\mathrm{Cl}^{-}$(ZADUNAISKY et al., 1963).

The potential difference (PD) of the skin was measured (dermal side positive) at room temperature $\left(18-23^{\circ} \mathrm{C}\right)$ using a pair of calomel electrodes, a DC amplifier, and a millivoltmeter. A current was applied across the skin through a pair of silver electrodes. The short circuit current (SCC) was determined by adjusting the PD to zero manually (Ussing and ZeraHn, 1951). The methods for measuring the PD and SCC were as described in detail previously (HAYASHI et al., 1977). The skin resistance $\left(R_{\mathrm{M}}\right)$ was calculated using the equation: $R_{\mathrm{M}}=\mathrm{PD} / \mathrm{SCC}$.

The skin, in the open-circuit condition, was allowed to equilibrate with the control bathing solution for at least $3 \mathrm{hr}$ before commencing the experiments.

Cadmium and/or amiloride were applied to the epidermal side of the skin in saline containing $\mathrm{CdSO}_{4}$ and/or amiloride $\mathrm{HCl}$.

All results were normalized to values obtained with control skin $(100 \%)$, and expressed as the mean value and one standard error of the mean. 
Table 1. Composition of the Ringer's solution (mM) with various [Ca].

\begin{tabular}{lcccccc}
\hline & Ca-free & $1-\mathrm{Ca}$ & $5.25-\mathrm{Ca}$ & $9.5-\mathrm{Ca}$ & $18-\mathrm{Ca}$ & $35-\mathrm{Ca}$ \\
\hline $\mathrm{Na}_{2} \mathrm{SO}_{4}$ & 55 & 55 & 55 & 55 & 55 & 55 \\
$\mathrm{~K}_{2} \mathrm{SO}_{4}$ & 1 & 1 & 1 & 1 & 1 & 1 \\
Ca-gluconate & 0 & 1 & 5.25 & 9.5 & 18 & 35 \\
Glucose & 10 & 10 & 9 & 8 & 6 & 2 \\
Sucrose & 60 & 60 & 52.5 & 45 & 30 & 0 \\
Tris- $\mathrm{H}_{2} \mathrm{SO}_{4}$ & 10 & 10 & 10 & 10 & 10 & 10 \\
pH & 7.2 & 7.2 & 7.2 & 7.2 & 7.2 & 7.2 \\
\hline
\end{tabular}

Table 2. Composition of the Ringer's solution (mM) with various $\left[\mathrm{Na}^{+}\right]$.

\begin{tabular}{lccccc}
\hline & $110-\mathrm{Na}$ & $60-\mathrm{Na}$ & $30-\mathrm{Na}$ & $10-\mathrm{Na}$ & $4-\mathrm{Na}$ \\
\hline $\mathrm{Na}_{2} \mathrm{SO}_{4}$ & 55 & 30 & 15 & 5 & 2 \\
$\mathrm{~K}_{2} \mathrm{SO}_{4}$ & 1 & 1 & 1 & 1 & 1 \\
Ca-gluconate & 0 & 0 & 0 & 0 & 0 \\
Glucose & 10 & 30 & 52 & 67 & 70 \\
Sucrose & 60 & 92 & 100 & 105 & 110 \\
Tris- $\mathrm{H}_{2} \mathrm{SO}_{4}$ & 10 & 35 & 50 & 60 & 61 \\
$\mathrm{pH}$ & 7.2 & 7.2 & 7.2 & 7.2 & 7.2 \\
\hline
\end{tabular}

\section{RESULTS}

\section{Effect of calcium on SCC}

The effect of various [calcium] on the short circult current (SCC) of bullfrog abdominal skin was investigated. The composition of the Ringer's solution in this series of experiments is shown in Table 1. The "1-Ca" saline on both sides was simultaneously replaced by a test saline about $3 \mathrm{hr}$ after setting up the skin preparation. Each test saline was applied for $20 \mathrm{~min}$, then it was replaced by the "1-Ca" saline. Recovery usually took about $30 \mathrm{~min}$.

Figure 1 summarizes the results of 32 experiments. Each data point is nor-

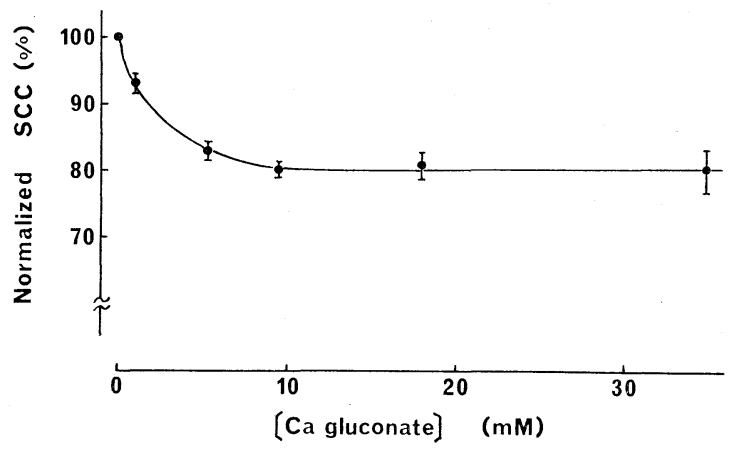

Fig. 1. Relationship between [Ca] and the short circuit current (SCC) of bullfrog skin.

$\left[\mathrm{Na}^{+}\right]=110 \mathrm{~mm}$. The SCC is normalized with respect to that in "Ca-free" saline.

The vertical bar on each data point represents the standard error of the mean. 


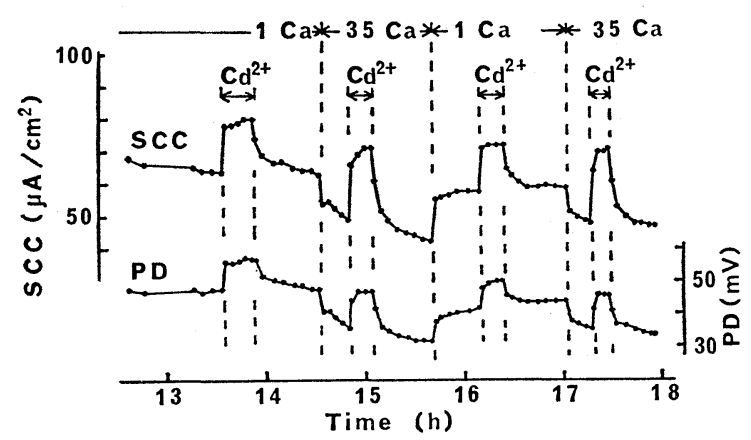

Fig. 2. Effects of $1 \mathrm{mM} \mathrm{Cd}{ }^{2+}$ on the SCC and potential difference (PD) in "1-Ca" and "35-Ca" saline. $\left[\mathrm{Na}^{+}\right]=110 \mathrm{~mm}$.

malized with respect to the SCC in the "Ca-free" saline, and represents the average of 5 to 6 experiments. The SCC was inhibited by the addition of Ca gluconate; the higher the [calcium], the less the SCC became. Sodium transport current was not completely inhibited by calcium. Maximum inhibition was observed at a [calcium] of over $8 \mathrm{~mm}$, where the SCC decreased to $80 \%$ of control. The concentration of calcium at half-maximum inhibition was $1.4 \mathrm{~mm}$.

\section{Effect of $\mathrm{Cd}^{2+}$ at different [calcium]}

It has been demonstrated that epidermally applied $\mathrm{Cd}^{2+}$ increases the SCC. This $\mathrm{Cd}^{2+}$-induced increase in SCC was examined at various [calcium] (see Table 1) on both sides of the skin.

Figure 2 illustrates a typical example of the effect of $1 \mathrm{mM} \mathrm{Cd}^{2+}$ on the SCC in "1-Ca" and "35-Ca" saline. The preparation was soaked in the "1-Ca" saline for about $4 \mathrm{hr}$, and $\mathrm{Cd}^{2+}$ was first applied epidermally for $20 \mathrm{~min}$ when both the SCC and PD attained a new steady level. The SCC and PD were increased to 125.0 and $120.2 \%$, respectively, and the $R_{\mathrm{M}}$ was decreased to $95.6 \%$. After washing the skin with the "1-Ca" saline, the bathing solution was substituted by " 35 Ca" saline. After $20 \mathrm{~min}$, the SCC and PD decreased to 80.3 and $80.0 \%$, respectively. Then $\mathrm{Cd}^{2+}$ was added to the " $35-\mathrm{Ca}$ " epidermal solution to a final concentration of $1 \mathrm{~mm}$. The SCC and PD increased to 144.9 and $130.5 \%$, respectively, and the $R_{\mathrm{M}}$ decreased to $89.6 \%$ compared to the values just prior to the application of $\mathrm{Cd}^{2+}$. The results of the second $\mathrm{Cd}^{2+}$ application in the " $1-\mathrm{Ca}$ " and " $35-\mathrm{Ca}$ " saline were similar to those of the first.

The results of 8 experiments of this type are summarized as follows. Cadmium at $1 \mathrm{~mm}$ increased the SCC by $27.6 \pm 5.8 \%$ in " $1-\mathrm{Ca}$ " saline, while the $\mathrm{Cd}^{2+}$ induced increase of the SCC was greatly enhanced in "35-Ca" saline $(45.1 \pm$ $6.7 \%)$. The difference in the effect of $\mathrm{Cd}^{2+}$ was highly significant $(P<0.003)$. The results of the second $\mathrm{Cd}^{2+}$ application in the " $1-\mathrm{Ca}$ " and " $35-\mathrm{Ca}$ " saline were similar to those of the first: $33.2 \pm 5.7 \%$ in the " $1-\mathrm{Ca}$ " saline, and $50.6 \pm 5.3 \%$ in the " $35-\mathrm{Ca}$ " saline. Again, the difference in the $\mathrm{Cd}^{2+}$-induced increase of the 

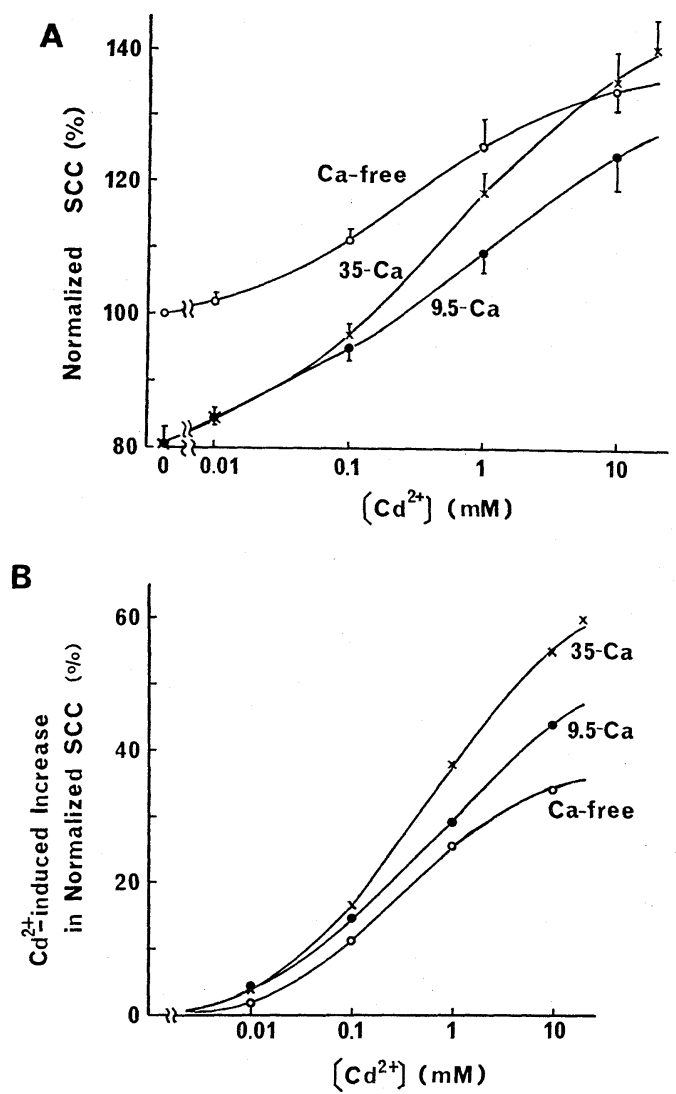

Fig. 3. Relationship between $\left[\mathrm{Cd}^{2+}\right]$ and the $\mathrm{SCC}$ at various $[\mathrm{Ca}] . \quad\left[\mathrm{Na}^{+}\right]=110 \mathrm{~mm}$. The $\mathrm{SCC}$ is normalized with respect to that in "Ca-free" saline (Fig. 3A). The same data are replotted for the relationship, $\left(\mathrm{SCC}_{\mathrm{Cd}}-\mathrm{SCC}_{\mathrm{Cd}-\mathrm{free}}\right)$ vs. $\left[\mathrm{Cd}^{2+}\right]$, in Fig. 3B. Open circles, closed circles and crosses indicate data for "Ca-free," "9.5-Ca," and "35-Ca" saline, respectively.

SCC was highly significant $(P<0.01)$ in the second " $1-\mathrm{Ca}$ " and " $35-\mathrm{Ca}$ " saline. However, no significant differences were observed between the results of the first and second $\mathrm{Cd}^{2+}$ application in the "1-Ca" saline $(P>0.5)$ or between those in the "35-Ca" saline $(P>0.1)$.

Figure $3 \mathrm{~A}$ shows the relationship between $\left[\mathrm{Cd}^{2+}\right]$ and the SCC at [calcium] of $0,9.5$, and $35 \mathrm{~mm}$ (see Table 1). Each data point is normalized with respect to the SCC in Cd-free "Ca-free" saline, and represents the average of 5 to 9 experiments. The SCC in the "9.5-Ca" saline was less than in the "Ca-free" saline at all $\left[\mathrm{Cd}^{2+}\right]$ tested. In the $\mathrm{Cd}^{2+}$-free condition, the $\mathrm{SCC}$ was decreased to almost the same extent in both the "35-Ca" and "9.5-Ca" saline. However, the SCC in the "35-Ca" saline appeared to be larger than that in the "Ca-free" saline for over $10 \mathrm{mM} \mathrm{Cd}^{2+}$. 




Fig. 4. Hill plot of the $\mathrm{Cd}^{2+}$-induced increase in $\mathrm{SCC} v s .\left[\mathrm{Cd}^{2+}\right]$ in "Ca-free" saline. The data are taken from Fig. 3, and the linear regression line was fitted by the method of least squares.

Figure 3B shows the dose-response curve of the $\mathrm{Cd}^{2+}$-induced increase in $\mathrm{SCC},\left(\mathrm{SCC}_{\mathrm{Cd}}-\mathrm{SCC}_{\mathrm{Cd}-\text { free }}\right) v s .\left[\mathrm{Cd}^{2+}\right]$ at various [calcium], replotted from the data shown in Fig. 3A. As $\left[\mathrm{Cd}^{2+}\right]$ increases, so the $\mathrm{Cd}^{2+}$-response increase in a sigmoid manner. This curve shifts upwards as [calcium] becomes greater. The curve appears to coincide with the following equation:

$$
\mathrm{SCC}=\mathrm{SCC}_{\max } /\left(1+10^{-\left(k_{1} \cdot \log \left[\mathrm{Cd}^{2}+\right]+k_{2}\right)}\right),
$$

where $k_{1}$ and $k_{2}$ are constants. In order to determine the values of the constants in the equation, a Hill plot was drawn from the data.

The logarithmic form of the Hill equation in enzyme kinetics gives a linear relationship for $\log \left[v /\left(V_{\max }-v\right)\right] v s .(n \cdot \log [\mathrm{S}]-\log K)$, where $[\mathrm{S}]$ is the substrate concentration, $v$ and $V_{\max }$ are the velocity and maximum velocity of the reaction, and $n$ and $K$ are constants (SEGEL, 1975). The same equation is used for the analysis of the relationship between the $\mathrm{Cd}^{2+}$-induced increase in SCC and $\left[\mathrm{Cd}^{2+}\right]$ ( $v$ and $[\mathrm{S}]$ in the above equation) (Fig. 4). From the data in Fig. 3B, the $V_{\max }$ in the "Ca-free" saline was estimated to be $37 \%$. The linear regression line for the Hill plot was fitted by the method of least squares. The slope of the line $(n)$ is 0.737 , which is clearly less than unity, suggesting that the binding reaction between $\mathrm{Cd}^{2+}$-binding sites and $\mathrm{Cd}^{2+}$ is not of the Michaelis-Menten type, but of the sigmoid type which exhibits negative cooperation (see SEGEL, 1975). The intersection of the Hill plot and a horizontal line at $v=V_{\max } / 2(y=0)$ gives $[\mathrm{S}]_{0.5}$ as $341 \mu \mathrm{M}$. The Hill coefficients $(n)$ in the "9.5-Ca" and "35-Ca" salines were almost identical to that in the "Ca-free" saline. The constants in Eq. (1), $k_{1}$ and $k_{2}$, were expressed in terms of the constants in the Hill plot as $n$ and $-\log [\mathrm{S}]_{0.5}^{\mathrm{n}}$, respectively.

\section{Effects of $\mathrm{Ca}$ and $\mathrm{Cd}^{2+}$ at different $\left[\mathrm{Na}^{+}\right]$}

Figure 5 illustrates the influence of various $\left[\mathrm{Na}^{+}\right]$(Table 2$)$ on the $\mathrm{SCC}$ in the 


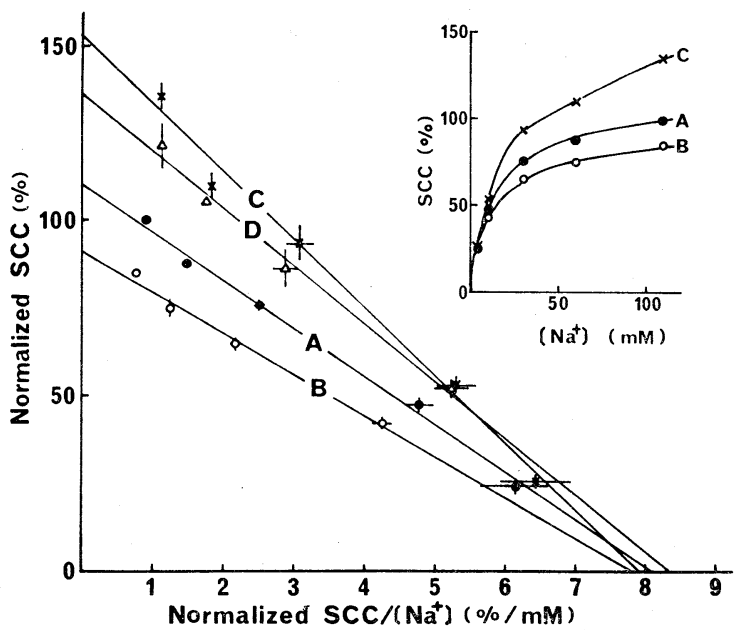

Fig. 5. Eadie-Hofstee plot of (normalized SCC) $v s$. (normalized SCC) $/\left[\mathrm{Na}^{+}\right]$. The SCC was normalized with respect to that in Ca-free Cd-free $110 \mathrm{~mm}\left[\mathrm{Na}^{+}\right]$. The inset shows the relationship between $\left[\mathrm{Na}^{+}\right]$and the normalized SCC. A, control saline in Table 2; $\mathrm{B},+5 \mathrm{~mm} \mathrm{Ca} ; \mathrm{C},+2 \mathrm{~mm} \mathrm{Cd} ; \mathrm{D},+5 \mathrm{~mm} \mathrm{Ca}+2 \mathrm{~mm} \mathrm{Cd}$.

presence or absence of $2 \mathrm{mM} \mathrm{Cd}^{2+}$ and/or $5 \mathrm{~mm}$ calcium. The Ca-containing Ringer's solution was prepared by dissolving gluconate in the Ca-free saline. All data were normalized with respect to the SCC in "110-Na" saline. The inset shows the relationship between the SCC and $\left[\mathrm{Na}^{+}\right]$in control (A), $+5 \mathrm{~mm} \mathrm{Ca}(\mathrm{B})$, and $+2 \mathrm{~mm} \mathrm{Cd}(\mathrm{C})$ salines. It was demonstrated that $\mathrm{Ca}$ inhibited the SCC (B) and $\mathrm{Cd}^{2+}$ activated it (C) at each $\left[\mathrm{Na}^{+}\right]$. The slopes of the Hill plots of $\log [\mathrm{SCC} /$ $\left.\left(\mathrm{SCC}_{\max }-\mathrm{SCC}\right)\right] v s . \log \left[\mathrm{Na}^{+}\right]$in the control, $+5 \mathrm{~mm} \mathrm{Ca},+2 \mathrm{~mm} \mathrm{Cd}$, and $+5 \mathrm{~mm}$ $\mathrm{Ca}+2 \mathrm{~mm} \mathrm{Cd}$ saline, were $1.02,1.08,1.03$, and 1.11 , respectively. Since the values of the Hill coefficients are close to unity, all these relations for $\mathrm{Na}^{+}$are considered to belong to the Michaelis-Menten type.

A single reciprocal plot (Eadie-Hofstee plot) was drawn of SCC vs. SCC/ $\left[\mathrm{Na}^{+}\right]$. The equation can be expressed as follows: $\mathrm{SCC}=-K\left(\mathrm{SCC} /\left[\mathrm{Na}^{+}\right]\right)+$ $\mathrm{SCC}_{\max }$, where $-K$ is the slope of the line, and $\mathrm{SCC}_{\max }$ is as extrapolated saturated value of the $\mathrm{SCC}$ at $\left[\mathrm{Na}^{+}\right] \rightarrow \infty$. Each data point represents the average of 6 to 12 experiments. The linear regression line was fitted by the method of least squares for the data for each saline. The intercepts of the regression line on the $Y$-axis, $\mathrm{SCC}_{\text {max }}$, in $\mathrm{A}, \mathrm{B}, \mathrm{C}$, and $\mathrm{D}(+5 \mathrm{~mm} \mathrm{Ca}+2 \mathrm{~mm} \mathrm{Cd})$ saline were $110.3,91.7$, 153.6 , and $136.3 \%$, respectively; i.e., the order of $\mathrm{SCC}_{\max }$ was $(\mathrm{C})>(\mathrm{D})>(\mathrm{A})>$ (B). The slopes of the lines $(K)$ can be classified into two groups; control dissociation constant, $K_{\mathrm{S}}$ and dissociation constant with an activator or an inhibitor, apparent $K_{\mathrm{S}}$. The $K_{\mathrm{S}}$ in A was $13.7 \mathrm{~mm}$, and the apparent $K_{\mathrm{S}}$ in B, C, and D saline were $11.8,19.5$, and $16.4 \mathrm{~mm}$, respectively.

All the regression lines converged to a point on the $X$-axis $(0,8.00)$. The 
difference in values of the $X$-intercept was not significant $(P>0.04)$. This implies that $\mathrm{Ca}(\mathrm{B})$ and $\mathrm{Cd}^{2+}(\mathrm{C})$ are an inhibitor and an activator of uncompetitive type for active $\mathrm{Na}$ transport, respectively.

The SCC in Ca saline (B) was increased to that in (D) by the addition of $\mathrm{Cd}^{2+}$, but the difference between the SCC in (D) and (B) was always greater than that in (C) and (A) for each $\left[\mathrm{Na}^{+}\right]$. In other words, the effect of $\mathrm{Cd}^{2+}$ with $\mathrm{Ca}$ was greater than that without $\mathrm{Ca}$. This conclusion is in accordance with that derived from Fig. 3.

\section{Effect of amiloride on SCC}

Amiloride is known to be a blocker of active $\mathrm{Na}$ transport. The mechanism of amiloride inhibition on the SCC in bullfrog skin was then investigated. The "1-Ca" saline in Table 1 was employed in the experiments. Amiloride was applied to the skin epidermally in a similar manner to the application of $\mathrm{Cd}^{2+}$.

Figure 6 summarizes the results of 78 experiments. Each data point is normalized with respect to the SCC in amiloride-free " $1-\mathrm{Ca}$ " saline, and represents the average of 5 to 15 experiments. The SCC was inhibited by the addition of amiloride: the higher the [amiloride], the greater the inhibition became. The SCC was almost completely inhibited $\left(92.1 \%\right.$ ) at $5 \times 10^{-5} \mathrm{M}$ amiloride, and the [amiloride] at half-maximum inhibition was $2.8 \times 10^{-7} \mathrm{M}$.

By replotting the data in Fig. 6, the Hill coefficient $\left(n^{\prime}\right)$ of amiloride was obtained as 0.757 . This $n^{\prime}$ value, being clearly less than unity, suggests that the reaction is not of the Michaelis-Menten type, but of the sigmoid type which exhibits negative cooperation.

\section{Effect of $\mathrm{Cd}^{2+}$ at different [amiloride]}

The $\mathrm{Cd}^{2+}$-induced increase in the SCC was examined under the influence of epidermal application of various [amiloride] in "1-Ca" saline (Table 1). Figure 7



Fig. 6. Relationship between [amiloride] and SCC. $\left[\mathrm{Na}^{+}\right]=110 \mathrm{~mm}$. The SCC is normalized with respect to that in amiloride-free "1-Ca" saline. 


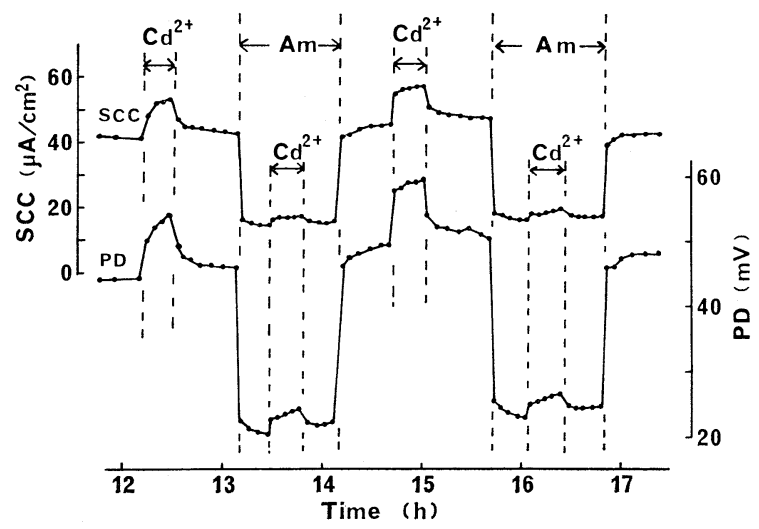

Fig. 7. Effects of $1 \mathrm{mM} \mathrm{Cd}^{2+}$ on the SCC and PD in the presence and absence of $5 \times 10^{-7} \mathrm{M}$ amiloride (Am). The effects of $\mathrm{Cd}^{2+}$ and amiloride were tested in "1-Ca" saline.

gives an example of the effect of $1 \mathrm{mM} \mathrm{Cd}^{2+}$ in the presence or absence of $5 \times 10^{-7} \mathrm{M}$ amiloride. Twenty min after the first application of the $\mathrm{Cd}^{2+}$, the SCC and PD were increased to 126.2 and $121.3 \%$, respectively, and the $R_{\mathrm{M}}$ was decreased to $94.8 \%$. After washing the skin with the "1-Ca" saline, the bathing solution was substituted by $5 \times 10^{-7} \mathrm{M}$ amiloride containing " $1-\mathrm{Ca}$ " saline. The SCC and PD were decreased to 34.9 and $44.6 \%$, respectively, and the $R_{\mathrm{M}}$ was increased to $127.8 \%$ in the amiloride saline. When $1 \mathrm{mM} \mathrm{Cd}^{2+}$ further was added epidermally, the SCC and PD were increased to 116.0 and $119.5 \%$, respectively, as compared to the values just prior to the addition of $\mathrm{Cd}^{2+}$.

The influence of amiloride on the $\mathrm{Cd}^{2+}$-induced increase in SCC was examined in 11 cases. Cadmium at $1 \mathrm{~mm}$ increased the SCC by $25.5 \pm 4.2 \%$ in amiloride-free "1-Ca" saline. Both calcium and amiloride thus inhibit the SCC, but the mechanism of the two inhibition processes may differ. The $\mathrm{Cd}^{2+}$ effect was almost doubled in "35-Ca" saline, while the $\mathrm{Cd}^{2+}$-induced increase in SCC was reduced to almost half in $5 \times 10^{-7} \mathrm{M}$ amiloride saline $(11.2 \pm 1.6 \%, n=11)$. The difference in the effects of $\mathrm{Cd}^{2+}$ in the absence or presence of amiloride was highly significant $(P<0.005)$. The second application of $\mathrm{Cd}^{2+}$ yielded essentially similar results to the first: $22.5 \pm 2.5 \%$ in the amiloride-free saline and $12.7 \pm$ $2.2 \%$ in $5 \times 10^{-7} \mathrm{M}$ amiloride saline. No significant differences were observed between the results of the first and second $\mathrm{Cd}^{2+}$ applications in the presence or absence of amiloride $(P>0.5)$.

Figure $8 \mathrm{~A}$ shows the relationship between $\left[\mathrm{Cd}^{2+}\right]$ and the SCC at [amiloride] of $0,10^{-7}, 5 \times 10^{-7}$, and $5 \times 10^{-6} \mathrm{M}$ in " $1-\mathrm{Ca}$ " saline (Table 1). Each data point is normalized with respect to the SCC in $\mathrm{Cd}^{2+}$-free and amiloride-free "1-Ca" saline, and represents the average of 6 to 11 experiments. The SCC became smaller with higher [amiloride], and became larger with higher $\left[\mathrm{Cd}^{2+}\right]$. No intersection of any two curves was observed which was different from the case of the $\mathrm{Cd}^{2+}$. effect under the influence of $\mathrm{Ca}(c f$. Fig. 3A). 

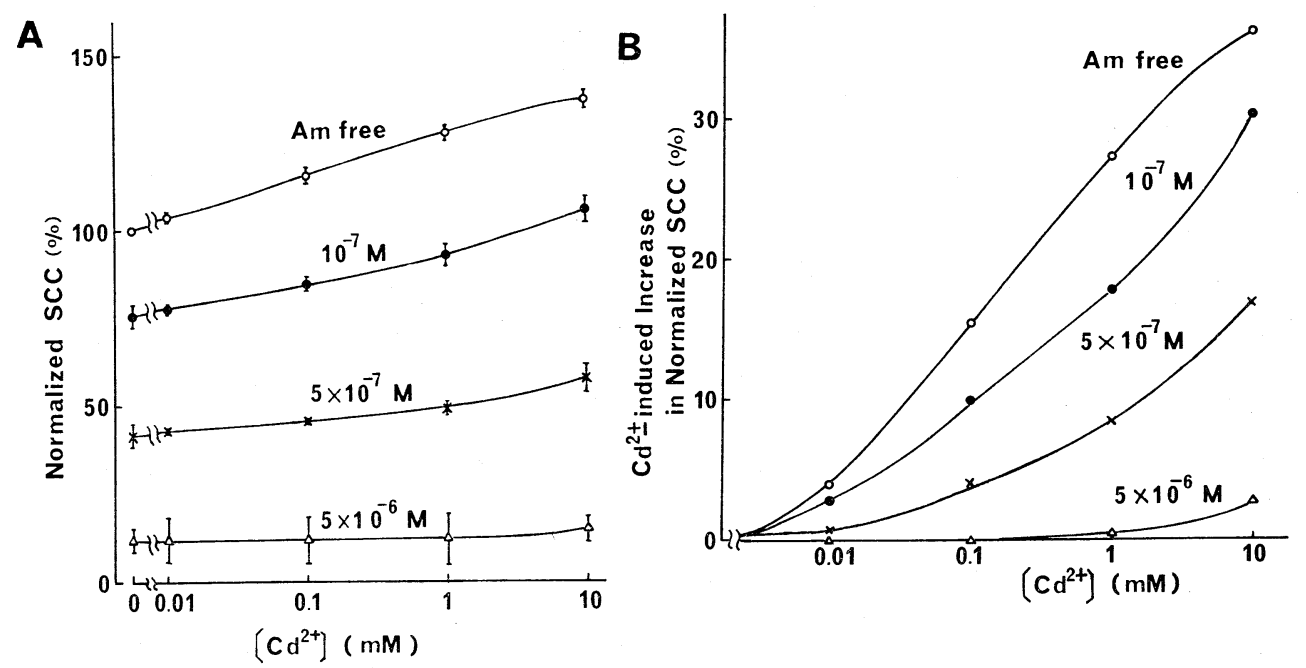

Fig. 8. Relationship between $\left[\mathrm{Cd}^{2+}\right]$ and the SCC at various [amiloride]. The SCC is normalized with respect to that in $\mathrm{Cd}^{2+}$-free " $1-\mathrm{Ca}$ " saline (Fig. $8 \mathrm{~A}$ ). The same data are replotted for the relationship, $\left(\mathrm{SCC}_{\mathrm{Cd}^{-}}-\mathrm{SCC}_{\mathrm{Cd}-\mathrm{free}}\right)$ vs. $\left[\mathrm{Cd}^{2+}\right]$, in Fig. 8B. Open circles, closed circles, crosses, and triangles indicate data for " 0 ," " $10^{-7} \mathrm{M}, "$ " $5 \times$ $10^{-7} \mathrm{M}$," and " $5 \times 10^{-6} \mathrm{M}$ " amiloride saline, respectively.

Figure $8 \mathrm{~B}$ shows the dose-response curves of $\left(\mathrm{SCC}_{\mathrm{Cd}}-\mathrm{SCC}_{\mathrm{Cd}-\mathrm{free}}\right) v s .\left[\mathrm{Cd}^{2+}\right]$ at various [amiloride], replotted from the data in Fig. 8A. As $\left[\mathrm{Cd}^{2+}\right]$ increases, so the $\mathrm{Cd}^{2+}$-response increases in a sigmiod manner, as in Fig. 3B. The main difference in the influence of calcium and amiloride is that, contrary to the former, the latter shifts the dose-response curve downwards when the [amiloride] becomes higher.

A Hill plot was drawn from the data in Fig. 8B. The same equation as in Fig. 4 was employed, and linear regression lines were drawn using the method of least squares. The slope of the linear regression line in the amiloride-free saline was 0.653 , and those in amiloride-containing saline were almost the same. Those values were clearly less than unity, suggesting that the binding reaction between $\mathrm{Cd}^{2+}$-binding sites and $\mathrm{Cd}^{2+}$ under the influence of amiloride is not of the Michaelis-Menten type but is negative cooperation type as in the case of the reaction under the influence of calcium. The $[\mathrm{S}]_{0.5}$ values $\left(i . e .,\left[\mathrm{Cd}^{2+}\right]\right.$ for $\left.v=V_{\max } / 2\right)$ at 0 , $10^{-7}$, and $5 \times 10^{-7} \mathrm{M}$ amiloride were $0.264,0.910$, and $1.65 \mathrm{~mm}$, respectively.

\section{Effect of $\mathrm{Cd}^{2+}$ and amiloride at different $\left[\mathrm{Na}^{+}\right]$}

Figure 9 illustrates the influence of various $\left[\mathrm{Na}^{+}\right]$(Table 2$)$ on the SCC in relation to the presence or absence of $\mathrm{Cd}^{2+}$ and/or amiloride. An Eadie-Hofstee plot was drawn of SCC vs. SCC/[Na+ $]$ using the same equation as in Fig. 5. Linear regression lines were drawn from the data for control saline (A), $+10^{-7} \mathrm{M}$ amiloride 


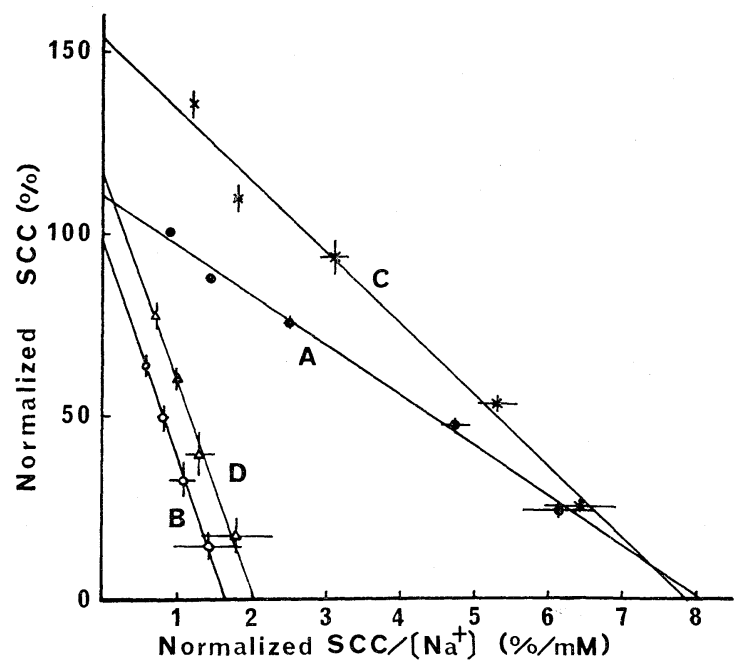

Fig. 9. Eadie-Hofstee plot of (normalized SCC) vs. (normalized SCC) $/\left[\mathrm{Na}^{+}\right] . \quad \mathrm{A}$, control saline in Table $2 ; \mathrm{B},+10^{-7} \mathrm{M}$ amiloride; $\mathrm{C},+2 \mathrm{~mm} \mathrm{Cd} ; \mathrm{D},+10^{-7} \mathrm{M}$ amiloride $+2 \mathrm{~mm}$ $\mathrm{Cd}$. The SCC was normalized with respect to that in amiloride-free Cd-free $110 \mathrm{~mm}$ $\left[\mathrm{Na}^{+}\right]$saline.

(B), $+2 \mathrm{~mm} \mathrm{Cd}(\mathrm{C})$, and $+10^{-7} \mathrm{~m}$ amiloride $+2 \mathrm{~mm} \mathrm{Cd}$ (D). $\mathrm{A}$ and $\mathrm{C}$ in Fig. 9 are identical to those in Fig. 5. All the data were normalized with respect to the SCC in " $110-\mathrm{Na}$ " saline, and each data point represents the average of 6 to 10 experiments. The intercepts of the regression line on the $Y$-axis, $\mathrm{SCC}_{\text {max }}$, in $\mathrm{A}$, $\mathrm{B}, \mathrm{C}$, and $\mathrm{D}$ saline were $110.3,97.2,153.6$, and $116.8 \%$, respectively; i.e., the order of $\mathrm{SCC}_{\max }$ was $(\mathrm{C})>(\mathrm{D})>(\mathrm{A})>(\mathrm{B})$. From the slope of the line, the $K_{\mathrm{S}}$ in A was $13.7 \mathrm{~mm}$, and the apparent $K_{\mathrm{S}}$ in $\mathrm{B}, \mathrm{C}$, and D saline were 58.8, 19.5, and $57.1 \mathrm{~mm}$, respectively. Amiloride (B) shifted the control line (A) downwards; the $Y$-intercept of $\mathrm{B}$ was significantly smaller than that of $\mathrm{A}(P<0.001)$, and the slope of B was clearly steeper than that of A. This suggests that the type of amiloride inhibition for $\mathrm{Na}$ entry is a mixed one. Addition of $\mathrm{Cd}^{2+}$ to amiloride saline (B) shifted the regression lines to the right almost in parallel (D). This shift indicates that the type of amiloride inhibition is also a mixed one even though in $\mathrm{Cd}^{2+}$-saline (D). It is interesting to note that although $\mathrm{Cd}^{2+}$ alone is an uncompetitive activator, $\mathrm{Cd}^{2+}$ in amiloride saline exhibits a different type of activation, i.e., a noncompetitive activation.

\section{DISCUSSION}

In active $\mathrm{Na}$ transport through frog skin, the relation between the $\mathrm{Na}$ transport and $\left[\mathrm{Na}^{+}\right]$is a hyperbolic curve which is convex upwards (CEREIJIDo et al., 1964). This saturable behavior is explained as follows. $\mathrm{Na}^{+}$moves into the frog skin by using a Na-selective molecule (BIBER and SANDERS, 1973) or through a 
pore (LINDEMANN and VAN DRIESSChe, 1977), which becomes saturated at high $\left[\mathrm{Na}^{+}\right]$. These characteristics make it possible to analyze the steady-state $\mathrm{Na}$ transport kinetics by using similar techniques to enzyme kinetics (BENOs et al., 1979; ACEves and Cuthbert, 1979). Specialized sites located on the outer membrane surface, which correspond to the reaction sites of an enzyme, appear to be responsible for Na saturation (ERLIJ and SMITH, 1973; MANDEL, 1978). Since $\mathrm{Cd}^{2+}$ was found to increase the SCC only when it was applied from the epidermal side, it appeared reasonable to apply the principles of enzyme kinetics for elucidating the mechanism of $\mathrm{Cd}^{2+}$ activation on $\mathrm{Na}^{+}$entry. A kinetic analysis of the effects of the well-known inhibitors, $\mathrm{Ca}$ and amiloride, and their interaction with that of $\mathrm{Cd}^{2+}$ was also performed. No other investigators have so far made kinetic studies on the $\mathrm{Cd}^{2+}$ effect.

Inhibitory effect of Ca on SCC. Calcium itself inhibits the SCC in a hyperbolic manner (Fig. 1). The limiting value of the curve in this paper was $80 \%$. Two possibilities may explain this partial inhibitory effect. The first is that the total current is divided into two fractions, one sensitive to, and the other insensitive to Ca (Curran and Gill, 1962), and the second is that Ca inhibits every channel related to active $\mathrm{Na}$ transport by $20 \%$ at maximum. The analysis utilized in this paper followed the second assumption due to its simplicity. The maximum Cainhibition of $20 \%$ indicated by our results is smaller than that $(60 \%)$ obtained by Curran and GILl (1962). This may be due to the difference in animal species employed and the composition of the Ringer's solution.

Facilitatory and inhibitory effects of $\mathrm{Ca}$ on the $\mathrm{Cd}^{2+}$-induced increase in SCC. HILlYARD and GONICK (1976) reported that the $\mathrm{Cd}^{2+}$ effects was not influenced by the addition of $\mathrm{Ca}$. However, we found that the effect of $\mathrm{Cd}^{2+}$ on the SCC was modified by changing the [Ca] as follows. (1) At a constant [Ca], the increase in SCC was higher at higher $\left[\mathrm{Cd}^{2+}\right]$ than at lower $\left[\mathrm{Cd}^{2+}\right]$ ( $f f$. Fig. 3B). (2) Ca facilitated the $\mathrm{Cd}^{2+}$-induced increase in SCC at higher [Ca] ( $c f$. Fig. 3B). (3) The Hill plot of SCC vs. $\left[\mathrm{Cd}^{2+}\right]$ shifted to the right almost in parallel at higher [Ca]. The ratio of the $\mathrm{Cd}^{2+}$-induced $\mathrm{SCC}$ at higher [Ca] to that at lower [Ca] increased with increasing $\left[\mathrm{Cd}^{2+}\right]$. MATSUMOTO and ChIHARA (1958) described both facilitatory and inhibitory effects of $\mathrm{Ca}^{2+}$ on acetylcholine (ACh)-induced contraction of rabbit small intestine: through the coexistence of higher $\left[\mathrm{Ca}^{2+}\right]$, the $\mathrm{ACh}$-induced contraction at lower $[\mathrm{ACh}]$ was depressed and that at higher $[\mathrm{ACh}]$ was enhanced. The effects of $\mathrm{Ca}$ on the $\mathrm{Cd}^{2+}$-induced increase in SCC may also consist of a facilitatory one (noncompetitive type) at higher $\left[\mathrm{Cd}^{2+}\right]$ (upward shift in Fig. 3B) and an inhibitory one (competitive type) at lower $\left[\mathrm{Cd}^{2+}\right]$ (shift to the right in Fig. 3B), even though $\mathrm{Ca}$ does not apparently depress the $\mathrm{Cd}^{2+}$-induced SCC at lower $\left[\mathrm{Cd}^{2+}\right]$.

It is interesting to note that although the effect of $\mathrm{Ca}$ on the SCC attained a maximum at $10 \mathrm{~mm} \mathrm{Ca}$ ( $c f$. Fig. 1), the effect of $\mathrm{Ca}$ on the $\mathrm{Cd}^{2+}$-induced $\mathrm{SCC}$ increased even at over $10 \mathrm{~mm} \mathrm{Ca}$ ( $c f$. Fig. 3B).

Interaction of $\mathrm{Ca}$ and $\mathrm{Cd} d^{2+}$ in relation to active $\mathrm{Na}$ transport. $\mathrm{Na}^{+}$on the 


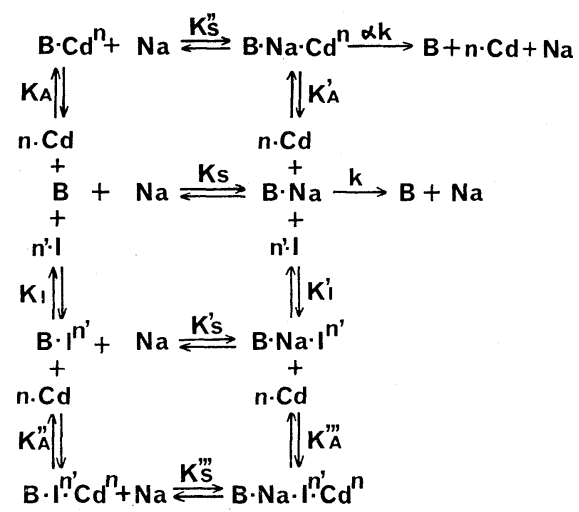

Fig. 10. Reactions related to active $\mathrm{Na}$ transport and their kinetic constants. B, a channel which has binding sites with either $\mathrm{Na}^{+}, \mathrm{Cd}^{2+}, \mathrm{Ca}$, or amiloride; $\mathrm{A}$, activator $\left(\mathrm{Cd}^{2+}\right)$; $\mathrm{I}$, inhibitor $(\mathrm{Ca}$, amiloride $=\mathrm{Am}) ; k$ and $\alpha k$, coefficients of $\mathrm{B} \cdot \mathrm{Na}$ and $\mathrm{B} \cdot \mathrm{Na} \cdot \mathrm{Cd}^{n} \mathrm{com}-$ plexes transformed into $\mathrm{SCC}(\alpha=1.4) . \quad \mathrm{B} \cdot \mathrm{Na} \cdot \mathrm{I}^{\prime \prime}$ and $\mathrm{B} \cdot \mathrm{Na} \cdot \mathrm{I}^{n^{\prime}} \cdot \mathrm{Cd}^{n}$ are assumed never to decompose so that they are not transformed into SCC. Hill coefficient $(n)$ : $n_{\mathrm{Cd}}=0.737, n_{\mathrm{Am}}^{\prime}=0.757$. Na-B, Michaelis-Menten type reaction; Cd (with or without $\mathrm{Ca}$ ), uncompetitive activator; $\mathrm{Ca}$, uncompetitive inhibitor; Am, mixed-type inhibitor; $\mathrm{Cd}$ (with Am), noncompetitive activator. Dissociation constants: $K_{\mathrm{S}}=13.7 \times 10^{-3}(\mathrm{M})$, $K_{\mathrm{A}(\mathrm{Am}+\mathrm{Cd})}=K_{\mathrm{A}}{ }^{\prime}=8.02 \times 10^{-3}\left(\mathrm{M}^{0.737}\right), K_{\mathrm{I}}{ }^{\prime}(\mathrm{Ca}, \mathrm{Ca}+\mathrm{Cd})=2.45 \times 10^{-2}(\mathrm{M}), K_{\mathrm{I}}{ }^{\prime}(\mathrm{Am}, \mathrm{Am}+\mathrm{Cd})=$ $3.72 \times 10^{-5}\left(\mathrm{M}^{0.757}\right), \quad K_{\mathrm{I}(\mathrm{Am}, \mathrm{Am}+\mathrm{Cd})}=1.29 \times 10^{-6}\left(\mathrm{M}^{0.757}\right), \quad K_{\mathrm{S}}^{\prime}(\mathrm{Am}, \mathrm{Am}+\mathrm{Cd})=K_{\mathrm{S}} \cdot K_{\mathrm{I}}{ }^{\prime} / K_{\mathrm{I}}=$ $3.96 \times 10^{-1}(\mathrm{M})$.

epidermal side is considered to bind with a channel (B) to form a $\mathrm{B} \cdot \mathrm{Na}$ complex which is transformed to the SCC during the subsequent process of decomposition of the $\mathrm{B} \cdot \mathrm{Na}$ complex (MANDEL, 1978). This idea may be expanded further as follows (Fig. 10). Binding sites of $\mathrm{Na}^{+}, \mathrm{Cd}^{2+}$, and $\mathrm{Ca}$ exist on the channel which is related to active $\mathrm{Na}$ transport. The SCC is produced by the decomposition of $\mathrm{B} \cdot \mathrm{Na}$ and $\mathrm{B} \cdot \mathrm{Na} \cdot \mathrm{Cd}^{n}(n=$ Hill coefficient $) . \mathrm{B} \cdot \mathrm{Na} \cdot \mathrm{I}^{n^{\prime}}$ and $\mathrm{B} \cdot \mathrm{Na} \cdot \mathrm{I}^{n \prime} \cdot \mathrm{Cd}^{n}(\mathrm{I}=$ $\mathrm{Ca}$ or amiloride) never decompose, so that no SCC is produced from these complexes. The capital letter " $K$ " represents a dissociation constant. The small letter " $k$ " represents the decomposition velocity of the $\mathrm{B} \cdot \mathrm{Na}$ complex, and " $\alpha k$ " is that of the $\mathrm{B} \cdot \mathrm{Na} \cdot \mathrm{Cd}^{n}$ complex, where $\alpha>1 . K$ and $k$ are termed kinetic constants.

The results of experiments on $\mathrm{Ca}, \mathrm{Cd}^{2+}$, or both in relation to the $\mathrm{SCC}$ at various $\left[\mathrm{Na}^{+}\right]$( $c f$. Fig. 5) indicate that these reactions belong to the uncompetitive type as regards the main reaction $(\mathrm{B}+\mathrm{Na} \rightleftharpoons \mathrm{B} \cdot \mathrm{Na})$ : both $\mathrm{Ca}$ and $\mathrm{Cd}^{2+}$ exert their effects by reversibly binding not to a $\mathrm{B}$ but to a $\mathrm{B} \cdot \mathrm{Na}$ complex solely. $\mathrm{Cd}^{2+}$ may also bind with a $\mathrm{B} \cdot \mathrm{Na} \cdot \mathrm{Ca}$ complex. Uncompetitive inhibition or activation is rarely observed in enzymology (DIXON and WEBB, 1979) or pharmacology (ARIËNS, 1964). In the skin of Rana pipiens, MANDEL (1978) reported that $\mathrm{Ca}^{2+}$ noncompetitively inhibited $\mathrm{Na}^{+}$entry, but from the Fig. 8 of CEREIJIDO et al. (1964), uncompetitive inhibition of a type similar to ours can be observed. Dis- 
Table 3. Relative values of various forms of channel $\cdot$ ion complex related to active $\mathrm{Na}$ transport (per unit surface area of frog skin).

\begin{tabular}{rcccccc}
\hline & $\begin{array}{c}\text { Control } \\
(110-\mathrm{Na})\end{array}$ & $\begin{array}{c}+2 \mathrm{mM} \\
\mathrm{Cd}\end{array}$ & $\begin{array}{c}+5 \mathrm{mM} \\
\mathrm{Ca}\end{array}$ & $+\mathrm{Ca}+\mathrm{Cd}$ & $\begin{array}{c}+10^{-7} \mathrm{M} \\
\mathrm{Am}\end{array}$ & $+\mathrm{Am}+\mathrm{Cd}$ \\
\hline$[\mathrm{B}]:$ & 11.1 & 5.2 & 9.4 & 4.5 & 7.2 & 3.1 \\
{$[\mathrm{~B} \cdot \mathrm{Na}]:$} & 88.9 & 41.6 & 75.3 & 36.2 & 57.4 & 25.4 \\
{$\left[\mathrm{~B} \cdot \mathrm{Na} \cdot \mathrm{Cd}^{n}\right]:$} & - & 53.2 & - & 46.2 & - & 32.2 \\
{$\left[\mathrm{~B} \cdot \mathrm{Cd}^{n}\right]:$} & - & - & - & - & - & 4.0 \\
{$\left[\mathrm{~B} \cdot \mathrm{Na} \cdot \mathrm{I}^{n}\right]:$} & - & - & 15.3 & 7.4 & 7.7 & 3.4 \\
{$\left[\mathrm{~B} \cdot \mathrm{I}^{n}\right]:$} & - & - & - & - & 27.7 & 12.2 \\
{$\left[\mathrm{~B} \cdot \mathrm{Na} \cdot \mathrm{I}^{\prime} \cdot \mathrm{Cd}^{n}\right]:$} & - & - & - & 5.8 & - & 4.3 \\
{$\left[\mathrm{~B} \cdot \mathrm{I}^{n^{\prime}} \cdot \mathrm{Cd}^{n}\right]:$} & - & - & - & - & - & 15.6 \\
{$[\mathrm{~B}$ total]: } & 100 & 100 & 100 & 100 & 100 & 100 \\
$\mathrm{SCC}_{\text {ex }}:$ & 100 & 131 & 82.8 & 119 & 63.8 & 76.9 \\
$\mathrm{SCC}_{\mathrm{ca} 1}:$ & 100 & 131 & 84.7 & 114 & 64.6 & 79.4 \\
\hline
\end{tabular}

$\mathrm{B}$, a channel which has binding sites with $\mathrm{Na}^{+}, \mathrm{Cd}^{2+}, \mathrm{Ca}$, or amiloride; I, inhibitor (Ca, amiloride); $\mathrm{SCC}_{\mathrm{ex}}$ and $\mathrm{SCC}_{\mathrm{cal}}$, experimental and calculated values of the normalized SCC, respectively, at $110 \mathrm{~mm}\left[\mathrm{Na}^{+}\right]$.

sociation constants for various reactions which appear in the equation of the law of mass action were obtained from the data in Fig. 5. Using these dissociation constants, the ratios of various forms of channel-ion complex were calculated. The calculated $\mathrm{SCC}\left(\mathrm{SCC}_{\mathrm{eal}}\right)$ was then compared with the experimentally obtained $\mathrm{SCC}\left(\mathrm{SCC}_{\mathrm{ex}}\right)$ (Table 3). The methods employed for the calculation are described in APPENDIX below. Assuming the kinetic constants to be invariable from those in individual agents $(+\mathrm{Ca}$, and $+\mathrm{Cd}$ saline), even in a mixture of the activator and inhibitor, $\mathrm{SCC}_{\mathrm{ea} 1}$ almost coincided with $\mathrm{SCC}_{\mathrm{ex}}$ in $(+\mathrm{Ca}+\mathrm{Cd})$-saline. Complete agreement was obtained if $\alpha=1.50$ was used instead of $\alpha=1.40$. If $\mathrm{B} \cdot \mathrm{Na}$. $\mathrm{Ca} \cdot \mathrm{Cd}^{n}$ is not formed at all, $\mathrm{SCC}_{\text {eal }}(121)=\mathrm{SCC}_{\text {ex }}$ (119) even under the condition of $\alpha=1.40$. However, from the type of reaction it was not possible to judge whether this complex was formed or not. In the case of $(+35 \mathrm{~mm} \mathrm{Ca}+2 \mathrm{~mm} \mathrm{Cd})-$ saline, assuming the kinetic constants to remain unchanged, some discrepancy exsited between $\mathrm{SCC}_{\mathrm{ca} 1}(102.5)$ and $\mathrm{SCC}_{\mathrm{ex}}$ (125.2). If we took $\alpha=1.7$, complete agreement was obtained for both. The increase in $\alpha$ value at higher [Ca] may correspond to a phenomenon in which the higher [Ca] facilitates the $\mathrm{Cd}^{2+}$-induced increase in the SCC further, as stated previously.

Inhibitory effect of amiloride on the $C d^{2+}$-induced increase in SCC. Amiloride has been found to inhibit the SCC by blocking $\mathrm{Na}^{+}$entry through the outer facing membrane of toad bladder (BENTLEY, 1968). SALAKo and SMITH (1970) obtained similar findings for frog skin. Amiloride inhibits not only the SCC but also the $\mathrm{Cd}^{2+}$-induced SCC. The effect of $\mathrm{Cd}^{2+}$ varied with the change in [amiloride] as follows. (1) At a constant [amiloride], both the SCC and $\mathrm{Cd}^{2+}$-induced SCC were higher at higher $\left[\mathrm{Cd}^{2+}\right]$ than at lower $\left[\mathrm{Cd}^{2+}\right]$ (cf. Fig. 8). (2) Amiloride inhibited the $\mathrm{Cd}^{2+}$-induced increase in SCC at higher [amiloride] (cf. Fig. 8B). (3) The Hill 
plot of SCC vs. $\left[\mathrm{Cd}^{2+}\right]$ shifted to the right at higher [amiloride]. According to the classification of MAтsumoto et al. (1955), such a non-Michaelis-Menten type of reaction (SCC vs. $\left[\mathrm{Cd}^{2+}\right]$ under the influence of amiloride) should be considered to represent inhibition of the mixed type (competitive and noncompetitive). The main differences between the effect of $\mathrm{Ca}$ and that of amiloride were that (1) at most only $20 \%$ inhibition was obtained with the former, and (2) there was no facilitation of the $\mathrm{Cd}^{2+}$-induced SCC with the latter.

Interaction of amiloride and $\mathrm{Cd}^{2+}$ in relation to active $\mathrm{Na}$ transport. A similar kind of kinetic analysis to that for $\mathrm{Ca}$ and $\mathrm{Cd}^{2+}$ in $\mathrm{Na}$ transport was performed for the interaction of amiloride and $\mathrm{Cd}^{2+}$. From the results in Fig. 9, amiloride inhibition was found to belong to the mixed type (both competitive and noncompetitive). In other words, amiloride exerts its effect by binding with a Na-selective channel (B) as well as a B $\cdot \mathrm{Na}$ complex with different dissociation constants. The binding site of amiloride on $\mathrm{B}$ is spatially distinct from the $\mathrm{Na}$ binding site.

Some discrepancies exist among other investigators concerning the type of amiloride inhibition. In toad bladder, BENTLEY (1968) claimed it to be a noncompetitive one, but SUDOU and HosHI (1977) asserted that it was a competitive one based on an analysis of the potential difference. In frog skin, from the data of SAlako and SMITH (1970, Fig. 4), the inhibition appeared to be of the mixed type. BENOS et al. (1979) described the amiloride inhibition as noncompetitive in bullfrog skin and as of the mixed type in toad skin. The differences in type of amiloride inhibition may arise from differences in the species of experimental animals employed, rearing conditions, Ringer's solution, and type of chambers. The mode of $\mathrm{Cd}^{2+}$ activation changed to the noncompetitive type under the influence of amiloride, which is different from the uncompetitive type of only $\mathrm{Cd}^{2+}$ or $\mathrm{Cd}^{2+}$ under the influence of $\mathrm{Ca}$. In other words, the data in Fig. 9 suggest that the conformation of the amiloride site is never affected by the addition of $\mathrm{Cd}^{2+}$ (compare $\mathrm{A} \rightarrow \mathrm{B}$ with $\mathrm{C} \rightarrow \mathrm{D}$ ). On the other hand, the conformation of the $\mathrm{Cd}^{2+}$ site is modified by amiloride (compare $\mathrm{A} \rightarrow \mathrm{C}$ with $\mathrm{B} \rightarrow \mathrm{D}$ ).

The Hill coefficient $\left(n^{\prime}=0.757\right)$ of amiloride in " $1-\mathrm{Ca}$ " saline was obtained by replotting the data in Fig. 6, and was estimated to be the same as that in "Cafree" saline from preliminary experiments. This corresponds with the results for bullfrog skin where the amiloride effect at $110 \mathrm{~mm}\left[\mathrm{Na}^{+}\right]$was not affected by the addition of $1 \mathrm{~mm} \mathrm{Ca}^{2+}$ (BENos et al., 1979). The $n^{\prime}$ value is clearly less than unity, suggesting that this reaction is not of the Michaelis-Menten type, but of the sigmoid type which exhibits negative cooperation. Our $n^{\prime}$ value is intermediate between the 0.86 of ACEves and Cuthbert (1979) and 0.54 of Benos et al. (1979). The ratios of various forms of channel-ion complex were calculated from the data in Fig. 9. Assuming the kinetic constants to be invariable from those in individual agents ( + amiloride, and $+\mathrm{Cd}^{2+}$ ), even in a mixture of the inhibitor and activator, $\mathrm{SCC}_{\mathrm{ca} 1}$ almost coincided with $\mathrm{SCC}_{\mathrm{ex}}$ in ( + amiloride $+\mathrm{Cd}^{2+}$ )-saline (Table 3). Complete agreement was obtained if $\alpha=1.33$ was postulated instead of 
$\alpha=1.40$.

Interaction of amiloride and $\mathrm{Ca}$ in relation to active $\mathrm{Na}$ transport. When $10^{-7}$ $\mathrm{M}$ amiloride and $5 \mathrm{mM} \mathrm{Ca}$ were administered to the frog skin simultaneously, the calculated ratio of $[\mathrm{B}]:[\mathrm{B} \cdot \mathrm{Na}]:[\mathrm{B} \cdot \mathrm{Na} \cdot \mathrm{Ca}]:\left[\mathrm{B} \cdot \mathrm{Am}^{n \prime}\right]:\left[\mathrm{B} \cdot \mathrm{Na} \cdot \mathrm{Am}^{n \prime}\right]:[\mathrm{B} \cdot \mathrm{Na} \cdot \mathrm{Ca} \cdot$ $\left.\mathrm{Am}^{n \prime}\right]$ at $110 \mathrm{mM}\left[\mathrm{Na}^{+}\right]$was $6.3: 50.7: 10.3: 24.5: 6.8: 1.4 \%$, where $n^{\prime}$ represents the Hill coefficient of amiloride, assuming the dissociation constants to be invariable. The calculated SCC was 57.0, which is in fairly good agreement with the experimentally obtained SCC (59.9). This also supports the assumption that the dissociation constants of the reaction were scarcely influenced by inhibitors.

Confirmation of the existence of various forms of channel $\cdot$ ion complex will require further detailed investigations.

Amiloride was supplied as a gift from Merck, Sharp \& Dohme, Rahway, New Jersey, 07065 U.S.A.

This study was supported in part by a Grant-in-Aid for the Encouragement of Young Scientists (577055) from the Ministry of Education, Science and Culture of Japan.

\section{APPENDIX}

This section indicates how to calculate the numerical data in Table 3. The abbreviations used are the same as those in Table 3.

In control saline, we obtained the dissociation constant $\left(K_{\mathrm{S}}\right)$ of the $\mathrm{B} \cdot \mathrm{Na}$ complex as $13.7 \mathrm{~mm}$ from the slope of Fig. 5 (line A). According to the law of mass action, $[\mathrm{B}][\mathrm{Na}] /[\mathrm{B} \cdot \mathrm{Na}]=13.7 \mathrm{~mm}$. Hence, $[\mathrm{B}]=0.125[\mathrm{~B} \cdot \mathrm{Na}]$, where $\left[\mathrm{Na}^{+}\right]=110$ mM. As $[\mathrm{B}]+[\mathrm{B} \cdot \mathrm{Na}]=[\mathrm{B}$ total $],[\mathrm{B}]:[\mathrm{B} \cdot \mathrm{Na}]=0.125: 1.00=11.1: 88.9 \%$. It is assumed that $[\mathrm{B} \cdot \mathrm{Na}]$ is directly proportional to the SCC. Since the SCC is normalized with respect to that in the control saline at $110 \mathrm{~mm}\left[\mathrm{Na}^{+}\right]$, the $\mathrm{SCC}$ becomes $k[\mathrm{~B} \cdot \mathrm{Na}]=100$ (arbitrary units), where $k$ is a constant. Then, $k[\mathrm{~B}$ total $]=112.5$.

Since $\mathrm{Cd}^{2+}$ is an uncompetitive activator of active $\mathrm{Na}$ transport (Fig. 5), the dissociations of the $[\mathrm{B} \cdot \mathrm{Na}]$ and $\left[\mathrm{B} \cdot \mathrm{Na} \cdot \mathrm{Cd}^{n}\right]$ complexes are related to two dissociation constants, $K_{\mathrm{S}}$ and $K_{\mathrm{A}}{ }^{\prime} . \quad K_{\mathrm{S}}$ is assumed to be the same as that in the control. $K_{\mathrm{A}}{ }^{\prime}$ is determined as follows: $K_{\mathrm{A}}{ }^{\prime}=[\mathrm{B} \cdot \mathrm{Na}]\left[\mathrm{Cd}^{n}\right] /\left[\mathrm{B} \cdot \mathrm{Na} \cdot \mathrm{Cd}^{n}\right]$. From Fig. 4 , the Hill coefficient $(n)=0.737$. Then, $\left[\mathrm{B} \cdot \mathrm{Na} \cdot \mathrm{Cd}^{n}\right]=\left(0.0103 / K_{\mathrm{A}}{ }^{\prime}\right)[\mathrm{B} \cdot \mathrm{Na}]$ at $2 \mathrm{mM}\left[\mathrm{Cd}^{2+}\right] . \quad \mathrm{SCC}_{\mathrm{Cd}([\mathrm{Na}+]=110 \mathrm{mM})}=k\left\{[\mathrm{~B} \cdot \mathrm{Na}]+\alpha\left[\mathrm{B} \cdot \mathrm{Na} \cdot \mathrm{Cd}^{n}\right]\right\}=131$, where $\alpha=$ $\mathrm{SCC}_{\mathrm{Cd}} / \mathrm{SCC}_{\mathrm{control}([\mathrm{Na}+] \rightarrow \infty)}=154 / 110=1.40$ (cf. Fig. 5 and SEGEL $(1975$, p. 229)). $[\mathrm{B}$ total $]=[\mathrm{B}]+[\mathrm{B} \cdot \mathrm{Na}]+\left[\mathrm{B} \cdot \mathrm{Na} \cdot \mathrm{Cd}^{n}\right]$. Hence, $K_{\mathrm{A}}{ }^{\prime}=8.02 \times 10^{-3}\left(\mathrm{M}^{0.737}\right)$. Then,

$$
[\mathrm{B}]:[\mathrm{B} \cdot \mathrm{Na}]:\left[\mathrm{B} \cdot \mathrm{Na} \cdot \mathrm{Cd}^{n}\right]=0.125: 1.00: 1.28=5.2: 41.6: 53.2 \% \text {; }
$$

and,

$$
\mathrm{SCC}_{\mathrm{cal}([\mathrm{Na}+]=110 \mathrm{mM})}=(41.6+53.2 \times 1.40) \times 100 / 88.9=131 .
$$

Since $\mathrm{Ca}$ is an uncompetitive inhibitor of active $\mathrm{Na}$ transport (Fig. 5), the inhibition constant $\left(K_{\mathrm{I}}{ }^{\prime}\right)$ or the dissociation constant of $[\mathrm{B} \cdot \mathrm{Na} \cdot \mathrm{Ca}]$ in $\mathrm{Ca}$ saline is 
obtained as follows: $\mathrm{SCC}_{\mathrm{a}}=\mathrm{SCC}_{\max } /\left(1+[\mathrm{Ca}] / K_{\mathrm{I}}{ }^{\prime}\right)$, where $\mathrm{SCC}_{\mathrm{a}}=$ apparent $\mathrm{SCC}_{\max ([\mathrm{Na}+] \rightarrow \infty)}$ in the Ca saline ( $c f$. Fig. 5 and SEGEL $\left(1975\right.$, p. 139)). $K_{\mathrm{I}}{ }^{\prime}=$ $[\mathrm{B} \cdot \mathrm{Na}][\mathrm{Ca}] /[\mathrm{B} \cdot \mathrm{Na} \cdot \mathrm{Ca}]$ at $5 \mathrm{~mm}[\mathrm{Ca}]=2.45 \times 10^{-2}(\mathrm{M})$. Hence, $[\mathrm{B} \cdot \mathrm{Na} \cdot \mathrm{Ca}]=$ $0.204\left[\mathrm{~B} \cdot \mathrm{Na}\right.$ ]. Assuming $K_{\mathrm{S}}$ to be the same as that in the control, [B]: [B-Na]: $[\mathrm{B} \cdot \mathrm{Na} \cdot \mathrm{Ca}]=0.125: 1.00: 0.204=9.4: 75.3: 15.3 \%$. Then, $\mathrm{SCC}_{\mathrm{cal}([\mathrm{Na}+]=110 \mathrm{mM})}$ $=75.3 \times 100 / 88.9=84.7$.

In $(+\mathrm{Cd}+\mathrm{Ca})$-saline, assuming $K_{\mathrm{S}}, K_{\mathrm{A}}{ }^{\prime}=K_{\mathrm{A}}{ }^{\prime \prime \prime}, K_{\mathrm{I}}{ }^{\prime}$, and $\alpha$ to be the same as those obtained previously,

$$
\begin{aligned}
{[\mathrm{B}]:[\mathrm{B} \cdot \mathrm{Na}]:\left[\mathrm{B} \cdot \mathrm{Na} \cdot \mathrm{Cd}^{0.737}\right]:[\mathrm{B} \cdot \mathrm{Na} \cdot \mathrm{Ca}]:\left[\mathrm{B} \cdot \mathrm{Na} \cdot \mathrm{Ca} \cdot \mathrm{Cd}^{0.737}\right] } \\
\quad=0.125: 1.00: 1.28: 0.204: 0.159=4.5: 36.2: 46.2: 7.4: 5.8 \% .
\end{aligned}
$$

The $\operatorname{SCC}_{\text {cal }\left(\left[\mathrm{Na}^{+}\right]=110 \mathrm{mM}\right)}=(36.2+46.2 \times 1.40) \times 100 / 88.9=114$. The calculated $\mathrm{SCC}$ agrees closely with the experimental value. If $\left[\mathrm{B} \cdot \mathrm{Na} \cdot \mathrm{Ca} \cdot \mathrm{Cd}^{0.737}\right]$ complex may not be formed $\left(K_{\mathrm{A}}{ }^{\prime \prime \prime}=\infty\right)$, then

$[\mathrm{B}]:[\mathrm{B} \cdot \mathrm{Na}]:\left[\mathrm{B} \cdot \mathrm{Na} \cdot \mathrm{Cd}^{0.737}\right]:[\mathrm{B} \cdot \mathrm{Na} \cdot \mathrm{Ca}]=4.8: 38.4: 49.0: 7.8 \%$, and the $\mathrm{SCC}_{\mathrm{cal}([\mathrm{Na}+]=110 \mathrm{mM})}=120$.

Since amiloride (Am) is a mixed-type inhibitor (Fig. 9), both $K_{\mathrm{I}}{ }^{\prime}$ and $K_{\mathrm{I}}$ should be determined. $\mathrm{SCC}_{\mathrm{a}}=\mathrm{SCC}_{\max } /\left(1+[\mathrm{Am}]^{n^{\prime}} / K_{\mathrm{I}}{ }^{\prime}\right)$. The Hill coefficient $\left(n^{\prime}\right)=$ 0.757. $[\mathrm{B} \cdot \mathrm{Na}]\left[\mathrm{Am}^{n \prime}\right] /\left[\mathrm{B} \cdot \mathrm{Na} \cdot \mathrm{Am}^{n \prime}\right]=K_{\mathrm{I}}{ }^{\prime} \cdot\left[\mathrm{B} \cdot \mathrm{Na} \cdot \mathrm{Am}^{n \prime}\right]=0.135[\mathrm{~B} \cdot \mathrm{Na}]$ at $10^{-7} \mathrm{M}$ [Am]. Hence, $K_{\mathrm{I}}{ }^{\prime}=3.72 \times 10^{-5}\left(\mathrm{M}^{0.757}\right) . \quad\left(K_{\mathrm{Am}} / \mathrm{SCC}_{\mathrm{Am}}\right) /\left(K_{\text {contro1 } 1} / \mathrm{SCC}_{\text {contro } 1}\right)=$ $1+\left[\mathrm{Am}^{n \prime}\right] / K_{\mathrm{I}}$, where $K_{\mathrm{Am}}$ and $K_{\mathrm{control}}$ are the slope of the $\mathrm{B}$ and $\mathrm{A}$ lines, and $\mathrm{SCC}_{\mathrm{Am}}$ and $\mathrm{SCC}_{\text {control }}$ are those at $\left[\mathrm{Na}^{+}\right]=\infty\left(c f\right.$. SEGEL $\left(1975\right.$, p. 171)). [B][Amm $\left.{ }^{\prime \prime}\right] /[\mathrm{B}$. $\left.\mathrm{Am}^{n \prime}\right]=K_{\mathrm{I}}=1.29 \times 10^{-6}\left(\mathrm{M}^{0.757}\right)$. Hence, $\left[\mathrm{B} \cdot \mathrm{Am}^{n \prime}\right]=3.88[\mathrm{~B}]=0.483[\mathrm{~B} \cdot \mathrm{Na}]$ at $10^{-7}$ $\mathrm{M}$ amiloride. Then,

$[\mathrm{B}]:[\mathrm{B} \cdot \mathrm{Na}]:\left[\mathrm{B} \cdot \mathrm{Na} \cdot \mathrm{Am}^{n \prime}\right]:\left[\mathrm{B} \cdot \mathrm{Am}^{n \prime}\right]$

$$
=0.125: 1.00: 0.135: 0.483=7.2: 57.4: 7.7: 27.7 \% \text {; }
$$

and

$$
\mathrm{SCC}_{\mathrm{ca1}([\mathrm{Na}+]=100 \mathrm{mM})}=57.4 \times 100 / 88.9=64.6 .
$$

In $(+\mathrm{Am}+\mathrm{Cd})$-saline, $\mathrm{Cd}^{2+}$ behaves as a noncompetitive activator for the Am-saline (Fig. 9). Therefore, [B] $\left[\mathrm{Cd}^{n}\right] /\left[\mathrm{B} \cdot \mathrm{Cd}^{n}\right]=K_{\mathrm{A}}=K_{\mathrm{A}}{ }^{\prime} . \quad K_{\mathrm{S}}{ }^{\prime}=K_{\mathrm{S}} \cdot K_{\mathrm{I}}{ }^{\prime} / K_{\mathrm{I}}=$ $3.96 \times 10^{-1}(\mathrm{M})$. Assuming that the $K_{\mathrm{S}}, K_{\mathrm{A}}{ }^{\prime}, K_{\mathrm{I}}, K_{\mathrm{I}}{ }^{\prime}$, and $\alpha$ in the $(+\mathrm{Am}+\mathrm{Cd})-$ saline are the same as those obtained previously,

$[\mathrm{B}]:[\mathrm{B} \cdot \mathrm{Na}]:\left[\mathrm{B} \cdot \mathrm{Na} \cdot \mathrm{Cd}^{n}\right]:\left[\mathrm{B} \cdot \mathrm{Cd}^{n}\right]:\left[\mathrm{B} \cdot \mathrm{Na} \cdot \mathrm{Am}^{n \prime}\right]:\left[\mathrm{B} \cdot \mathrm{Am}^{n \prime}\right]:\left[\mathrm{B} \cdot \mathrm{Am}^{n \prime} \cdot \mathrm{Cd}^{n}\right]:$

$\left[\mathrm{B} \cdot \mathrm{Na} \cdot \mathrm{Am}^{n \prime} \cdot \mathrm{Cd}^{n}\right]=0.125: 1.00: 1.28: 0.159: 0.135: 0.483: 0.618: 0.172$

$$
=3.1: 25.2: 32.2: 4.0: 3.4: 12.2: 15.6: 4.3 \% \text {. }
$$

The $\mathrm{SCC}_{\mathrm{ca}([\mathrm{Na}+]=110 \mathrm{mM})}=(25.2+32.2 \times 1.40) \times 100 / 88.9=74.9$. This value agrees closely with $\mathrm{SCC}_{\mathrm{ex}}(76.9)$. 


\section{REFERENCES}

ACeves, J. and CuthberT, A. W. (1979) Uptake of [ ${ }^{3} \mathrm{H}$ ]benzamil at different sodium concentrations. Inferences regarding the regulation of sodium permeability. J. Physiol. (Lond.), 295: 491-504.

ARiëNs, E. J. (1964) Molecular Pharmacology, Vol. 1, Academic Press, New York.

Benos, D. J., Mandel, L. J., and Balaban, R. S. (1979) On the mechanism of the amiloridesodium entry site interaction in anuran skin epithelia. J. Gen. Physiol., 73: 307-326.

Bentley, P. J. (1968) Amiloride: A potent inhibitor of sodium transport across the toad bladder. J. Physiol. (Lond.), 195: 317-330.

Biber, T. U. L. and SANDERS, M. L. (1973) Influence of transepithelial potential difference on the sodium uptake at the outer surface of the isolated frog skin. J. Gen. Physiol., 61: $529-551$.

Cereijido, M., Herrera, F. C., Flanigan, W. J., and Curran, P. F. (1964) The influence of $\mathrm{Na}$ concentration on Na transport across frog skin. J. Gen. Physiol., 47: 879-893.

Curran, P. F. and Gill, J. R., Jr. (1962) The effect of calcium on sodium transport by frog skin. J. Gen. Physiol., 45: 625-641.

Dixon, M. and WebB, E. C. (1979) Enzymes, Longman, London, pp. 341-345.

ERLIJ, D. and Smith, M. W. (1973) Sodium uptake by frog skin and its modification by inhibitors of transepithelial sodium transport. J. Physiol. (Lond.), 228: 221-239.

Hayashi, H., TaKadA, M., and Arita, A. (1977) Effects of cadmium on the active transport of sodium by the abdominal skin of a bullfrog (Rana catesbeiana). Jpn. J. Physiol., 27: $337-352$.

Hayashi, H., TAkada, M., and Arita, A. (1978) Cadmium-induced decrease in the outer facing skin resistance of a bullfrog (Rana catesbeiana). Jpn. J. Physiol., 28: 63-73.

Hillyard, S. D. and GonICK, H. C. (1976) Effects of $\mathrm{Cd}^{++}$on short-circuit current across epithelial membranes. I. Interaction with $\mathrm{Ca}^{++}$and vasopressin on frog skin. $J$. Membr. Biol., 26: 109-119.

LindemanN, B. and VAN Driessche, W. (1977) Sodium-specific membrane channels of frog skin are pores: Current fluctuations reveal high turnover. Science, 195: 292-294.

MANDEL, L. J. (1978) Effects of $\mathrm{pH}, \mathrm{Ca}, \mathrm{ADH}$, and theophylline on kinetics of $\mathrm{Na}$ entry in frog skin. Am. J. Physiol., 235: C35-C48.

Matsumoto, H. and Chinara, M. (1958) Types of drug synergism classified by the concentration-action curve. Jpn. J. Pharmacol., 8: 31-47.

Matsumoto, H., Miyake, T., Misawa, H., Matsuda, H., and Kumoi, T. (1955) The concentration-action curve of various drugs with special reference to the study of the mode of drug antagonism by means of the curve analysis. Kobe J. Med. Sci., 2: 347-362.

Salako, L. A. and Smith, A. J. (1970) Changes in sodium pool and kinetics of sodium transport in frog skin produced by amiloride. Br. J. Pharmacol., 39: 99-109.

Segel, I. H. (1975) Enzyme Kinetics, John Wiley, New York, pp. 139, 171, 229.

Stymans, A. and Borghgraef, R. (1969) The action of Cd on the Na-transport in the frog skin. Arch. Int. Physiol., 77: 334-335.

Sudou, K. and HosHI, T. (1977) Mode of action of amiloride in toad urinary bladder. $J$. Membr. Biol., 32: 115-132.

TAKADA, M. and HAYASHI, H. (1978a) Distribution of cadmium in the cross-section of cadmium-treated abdominal skin of a bullfrog. Analysis of $\mathrm{Cd}$ with an electron probe X-ray microanalyzer. Proc. Jpn. Acad., 54, Ser. B: 369-374.

TAKADA, M. and HAYASHI, H. (1978b) Effects of cadmium ion on the Na, K-ATPase of microsomes obtained from frog skin. Jpn. J. Physiol., 28: 473-483.

TAKADA, M. and HAYASHI, H. (1980a) Effect of cadimum on active sodium transport by the 
abdominal skin and the isolated epidermis of the bullfrog: Differences in effects between epidermal and dermal cadmium applications. Jpn. J. Physiol., 30: 257-269.

TAKADA, M. and HAYASHI, H. (1980b) Cadmium-induced increase in the active transport of sodium: Counteraction of calcium and amiloride with cadmium. J. Physiol. Soc. Jpn., 42: 232.

Ussing, H. H. and ZeRAHN, K. (1951) Active transport of sodium as the source of electric current in the short-circuited isolated frog skin. Acta Physiol. Scand., 23: 110-127.

Zadunaisky, J. A., Candia, O. A., and Chiarandini, D. J. (1963) The origin of the shortcircuit current in the isolated skin of the South American frog Leptodactylus ocellatus. $J$. Gen. Physiol., 47: 393-402. 